\title{
Critical Assessment of Prevention Policy Implementation of TAX Avoidance Practices Reviewed from the Accounting Perspective: A Study on Mining Companies in Indonesia
}

\section{David Luntungan*}

Department of Accounting, Airlangga University, Indonesia

*Corresponding author: David Luntungan, Department of Accounting, Airlangga University, Indonesia, Tel: 082322188787; E-mail: davidluntungan@outlook.com

Received date: Nov 20, 2018; Accepted date: Nov 26, 2018; Published date: Dec 03, 2018

Copyright: (C) 2018 Luntungan D. This is an open-access article distributed under the terms of the Creative Commons Attribution License, which permits unrestricted use, distribution, and reproduction in any medium, provided the original author and source are credited.

\begin{abstract}
The mining industry is one of the industrial sectors which are indicated to have carried out tax avoidance. Although it does not violate tax regulations, this has the potential to make the government unable to obtain taxes optimally from the mining industry. Therefore, the government strives to establish and implement various regulations to prevent tax avoidance conducted by the mining companies.

The objectives of this study are to:

- Review and describe the effectiveness of Indonesian government regulations and legislation related to prevention of tax avoidance practices in mining companies in Indonesia; and

- Reviewing and describing the compatibility between regulations and legislation with the provisions of taxation in Indonesia.

The research method used is descriptive qualitative. The research data was obtained using the documentation method and processed with the qualitative analysis techniques of Miles and Huberman which consisted of three stages of analysis, namely data reduction, data presentation, and conclusion drawing.

The results of the study state that:

- Regulations and legislation established and implemented by the Indonesian government to prevent tax avoidance in general are appropriate. However, these regulations and legislation have not been effectively used to overcome tax avoidance by mining companies; and

- Regulations and legislation to prevent tax avoidance have met the provisions of taxation in Indonesia.
\end{abstract}

Keywords: Mining companies; Taxes; Tax avoidance; Effectiveness of tax regulations

\section{Introduction}

Taxes are the main source of Indonesia's income, which amounts to Rp1,618.1 trillion or around $85 \%$ of total state revenues in 2018 . The large value of income from the tax sector encourages the government to continue to optimize revenues from the tax sector. In practice, the government's efforts often encountered several obstacles, one of which was related to the practice of tax avoidance by taxpayers.

Tax avoidance is a process of controlling actions to avoid the consequences of imposing tax that is not desired and as an act that is truly legal. Tax avoidance does not violate the law, because it is not categorized as violation or crime. Tax avoidance is done through tax control to avoid larger taxes or make taxpayers do not pay taxes at all [1].

Tax avoidance is considered as an act that does not violate the law because of the methods used generally by exploiting loopholes or shortcomings in existing tax regulations. Nevertheless, the essence of tax avoidance is actually not in accordance with the purpose of the existence of tax regulations, wherein on one hand it tends to be done by taxpayers to reduce the amount of tax that must be paid, but on the other hand trying to be prevented by the government in order to achieve tax revenue optimization [2].

One of the industrial sectors in Indonesia that has received strong attention from the government because of strong indications of tax avoidance is the mining industry. This is supported by some evidence from the government, that $70 \%$ of holders of Mining Business Permits (IUP) apparently do not have a Taxpayer Identification Number (NPWP) and are not willing to submit the data to the Director General of Taxes (DJP). It is also known that mining companies have been late to pay taxes up to tens of trillions of rupiah in 2016.

The action of those mining companies can be said to be included in tax avoidance because it has the characteristics of tax avoidance as mentioned by Ronen [3], namely:

- There is a tax payment in a value smaller than the value that should be in accordance with the scope of legal interpretation;

- Payment of taxes is adjusted to the profits announced, not to the profits which are actually obtained; and 
- There are efforts to delay payment of taxes. Given that the mining sector is one of the sectors that have a large contribution to Gross Domestic Product (GDP), Non-Tax State Revenues (PNPB), and General Land and Building Tax (PBB), the indications of tax avoidance make the government strive to establish various regulations to prevent this from happening.

Based on the overall explanation above, the formulation of the problems raised in this study are:

- How is the effectiveness of Indonesian government regulations and legislation related to the prevention of tax avoidance practices in mining companies in Indonesia? And

- Are these regulations and legislation fulfilling the provisions of taxation in Indonesia?

\section{Literature Review}

\section{Accounting theory}

The meaning of accounting can be seen based on two perspectives, namely the perspective of its activities and users. Based on the perspective of its activities, accounting is the process of recording, classifying, summarizing, reporting, and analyzing financial data held by an organization. If interpreted based on the perspective of the user, accounting is a field of science that provides guidelines for implementing financial data management activities efficiently [4].

Accounting theory is logical reasoning which includes a collection of principles that serve as a basis for analyzing accounting activities and developing new activity models in order to improve the efficiency of these activities [5]. Accounting theory is also the main reference used to overcome various problems that arise in accounting practices through methods that are scientific and ethical [6].

Accounting theory is divided into two types, namely normative accounting theory and positive accounting theory. Normative accounting theory is accounting theory that provides formulation of the implementation of accounting activities [7]. Deegan provide a more comprehensive explanation of the meaning of normative accounting theory as follows [8]:

"Normative theories prescribe how a particular practice should be undertaken and this prescription might be a significant departure from existing practice. A normative theory is generated as a result of the particular theorist applying some norm, standard, or objective against which actual practice should strive to achieve".

Normative accounting theory establishes two main objectives of accounting practice, namely to generate actual profits in an accounting period and to provide important data needed in the decision making process. According to Ghozali, normative accounting theory puts forward the value factor as the main reference in the formulation of guidelines for accounting practices, namely regarding how an activity in accounting activities must be carried out. However, these guidelines were created without going through a scientific testing process to prove the truth. Therefore, normative accounting theory is still limited to an untested concept to carry out various accounting activities.

Based on the existing shortcomings in normative accounting theory, positive accounting theory was developed which put forward the empirical method to analyze accounting activities. The results of the analysis are then used for the basis of developing the theory and establishing a solution model for the problems encountered in accounting practices [9].

The presence of positive accounting theory is then more widely used than normative accounting theory for three reasons, namely:

- Normative accounting theory cannot be used to test the theory empirically because of its inaccurate basic assumptions;

- Normative accounting orientation is only to encourage investor welfare without considering the welfare of other stakeholders; and

- Normative accounting theory is not able to optimally empower economic resources in the capital market [10].

Furthermore, Watt and Zimmerman explained that positive accounting theory seeks to provide an overview of the process of using accounting skills, understanding, and knowledge and the use of accounting policies that are most suitable for certain conditions in the future. Referring to this opinion, it is known that every individual, both a manager and an accountant, will optimally empower the utility when selecting an accounting method.

Positive accounting theory seeks to test three hypotheses, namely:

- Bonus program hypothesis;

- Debt or equity hypothesis; and

- Political Cost Hypothesis.

In the first hypothesis, namely the bonus program hypothesis, company managers with compensation plans tend to prefer methods that move future earnings into current earnings [11]. In this case for certain reasons, managers have incentives to "manipulate" or "regulate" reported earnings by using their authority through accounting methods that affect the size of profits. The choice is expected to increase the present value of the bonus he will receive if the compensation committee of the Board of Directors does not adjust to the chosen method.

The second hypothesis, namely the debt or equity hypothesis, is a hypothesis that states that there are consequences arising from changes in accounting methods as a result of lending and borrowing agreements, which include the costs of re-negotiating and overseeing debt agreements. If the costs for negotiation and monitoring are considered expensive, then it is not useful for managers to lobby and make changes to accounting methods voluntarily, even though these costs will reduce the value of the company. However, costs incurred as a result of changes in debt agreements are not significant and such changes will in many ways affect the prosperity of shareholders if followed by changes in accounting methods. The higher the debt/ equity ratio of the company, the more likely it is for managers to choose accounting methods that can increase profits. The higher the debt/equity ratio, the closer the company is to the credit limit/ agreement. The higher the credit limit, the greater the likelihood of credit agreement deviations and expenses. In this case the manager will choose an accounting method that can increase profits so that it can loosen credit limits and reduce the cost of technical errors.

The third hypothesis, namely the Political Cost hypothesis, states that the greater the company's political costs, the more likely the company manager to choose the accounting procedure that suspends earnings from the current period to the next period. For companies that are sensitive to political aspects, which tend to be in the spotlight of many people, the size of the profits reflected in accounting numbers will be translated differently by many parties. So managers in such companies have an interest in using a particular accounting method 
Page 3 of 8

and also have the possibility of lobbying that supports or rejects changes in accounting standards that must affect the company's political sensitivity. In general, large companies tend to use accounting methods that can reduce periodic profits compared to small companies. In this case the size of the company is a proxy variable from the political aspect. On the basis of information costs and monitoring costs, managers have an incentive to choose certain accounting profits in the political process.

The three hypotheses show that positive accounting theory recognizes the existence of three agency relationships, namely between management and owners, between management and creditors and the last is between management and the government. The agency problem arises because it is caused by the existence of information asymmetry between the agent and the principal, where the agent has more information than the principal [12].

\section{Agency theory}

Cooperation between owners and management of the company sometimes encounters several obstacles, which mainly occur because of differences of opinion and orientation between the two. The owner and management of the company are basically involved in a relationship called agency relations. In this connection, the owner of the company is domiciled as the principal, namely the party that gives trust and authority, to the management of the company that is domiciled as an agent, that is, the party given the trust and authority to manage the company.

The management orientation in managing the company is ideally aligned with the expectations of the principal, namely to achieve optimal company performance and provide maximum benefits to the principal. In practice, sometimes there is an information asymmetry between management and the owner. In this case, management as a party that is directly in touch with the entire line of companies has more detailed information about company performance than the owner. The difference in ownership of information is one of the loopholes that allow management to carry out management practices with an orientation for personal gain, no longer just to fulfill the interests of principals. This is the subject of agency theory initiated by Jensen and Meckling [13].

Information asymmetry between management and company owners can turn into agency conflict if differences in orientation between management and company owners cannot be resolved properly. The occurrence of agency conflicts is mainly caused by three things, namely:

- There is a tendency from management to overuse company resources;

- Lack of ownership from management over the company because management does not control the company's shares; and

- Management tends to make decisions that have the lowest risk of the security of their careers [14].

The parties who risk large losses due to agency conflicts are the owners of the company, so that the owner of the company needs extra effort to be able to control management. This is the basis for the emergence of agency costs, namely the costs that must be incurred by the owner of the company with the aim of obtaining maximum control of the company's management actions in order to ensure compliance with the expectations of the owner.
Agency theory bases its concept on three assumptions about human nature, namely:

- The tendency for selfishness;

- The limitations of thinking to make estimates; and

- There is a desire to always avoid risk. The three basic human traits underlie agency relationships that occur between the owner and management of the company, as well as being the starting point of analysis of various agency problems that arise [15].

\section{Tax avoidance}

Tax avoidance can be interpreted as an effort made by taxpayers to reduce or eliminate tax debts using methods that do not violate the statutory provisions set by the state. Through tax avoidance, the taxpayer, both in the form of individuals and companies, can reduce the amount of tax that must be paid, so that it will increase the cash flow owned [16,17].

Tax avoidance has three general characteristics, namely:

- There is an artificial affair in which various arrangements appear to be in it even though they are not, and this is done because of the absence of tax factors;

- Such schemes often use loopholes from the law or apply legal provisions for various purposes, even though that is not what the legislators intended; and

- Confidentiality also as a form of this scheme in which consultants generally show tools or ways to carry out tax avoidance with terms that the taxpayer should maintain its confidentiality.

Tax avoidance is carried out by taxpayers for several reasons, including:

- Amount of tax, where taxpayers have an increasing tendency to avoid taxation along with the increasing amount of tax to be paid;

- The cost of bribery to the tax authorities, where the smaller bribe costs will encourage the greater tendency of taxpayers to carry out tax avoidance;

- The possibility of being detected, where the less likely the detection of tax avoidance will encourage taxpayers to carry out tax avoidance; and

- Sanctions, where taxpayers will tend to avoid taxation if sanctions on these matters are smaller.

Tax avoidance is generally carried out by utilizing the weaknesses contained in the legislation, so that on the one hand, tax avoidance can provide benefits to taxpayers, while on the other hand, the government as the recipient of the tax becomes unable to obtain taxes optimally. Therefore, the government carries out various ways to minimize tax avoidance efforts by taxpayers. Two approaches commonly used by the government to reduce tax avoidance efforts are through judicial general anti avoidance doctrine (judicial doctrine) and statutory general anti avoidance rule.

The first approach, namely the judicial doctrine, was developed from court decisions related to tax avoidance. The principle of judicial doctrine is economic substance doctrine, step transaction doctrine, and substance over form doctrine. The first principle, namely economic substance doctrine, has the core that a transaction scheme that has the effect of reducing the tax burden can only be recognized if the transaction has economic substance, contains considerations other than taxes, and is not solely carried out for tax avoidance. 
Page 4 of 8

The second principle, the step transaction doctrine, is used in the case of Minnesota Tea Co. In that case, to pay the company's debt, Minnesota Tea Co. reorganized the company by exchanging assets and receiving shares and some money from other companies. The money is distributed to its shareholders in the form of profit distribution, then the shareholders hand over the money they receive to the debtor from Minnesota Tea Co. As a result of the transaction, because it is in the form of distribution to shareholders, it is not taxed, even though substantially the money is finally handed over to the shareholders to the company's debtor. In the appeal hearing, the judge decided not to accept the transaction, and canceled the tax avoidance scheme carried out. The judge essentially decided that because the end of the series of transactions was repayment of debt, then taxation would be treated as payment of tax-indebted debts [18].

The principle of substance over form basically explains that rights and obligations that arise formally as a result of transactions carried out by taxpayers will still be recognized, but the characterization of transactions carried out for tax purposes will be determined based on how substantially the tax regulations characterize the results of transactions, so that based on this principle, the facts and consequences of taxation of a transaction are determined based on commercial substance that arises and is not merely seen from its formal form [19].

The second approach to prevent tax avoidance is to make a general anti avoidance rule statutory in the form of special provisions that are included in tax regulations that aim to fight tax avoidance. Although in its formulation using different approaches, in general there are two main features implied in various statutory adopted by various countries, namely:

- The purpose of the transaction or the series of related transactions, and

- The alignment of the outcome of the transaction with the objective from related tax regulations.

\section{Research Methodology}

The type of this research is qualitative descriptive. Descriptive research is a research that seeks to gain an understanding of the focus of research by reviewing data to produce in-depth descriptions. The findings from descriptive research are broad and detailed which explain the focus of the problem along with the factors that have connectivity [20]. The approach used is a qualitative approach, namely an approach that seeks to understand the phenomenon that is thoroughly researched to gain a deep understanding based on the data collected and analyzed with reference to theoretical exposure [21]. The data of this study were obtained using the documentation method, namely by looking for data relating to the focus of research from internet sources. The data is in the form of an overview of mining companies in Indonesia, government regulations and policies to prevent tax avoidance practices, as well as theories and journals related to research topics. The data obtained were then analyzed using qualitative analysis techniques proposed by Huberman to answer the research problem formulation [22]. The analysis technique consists of three stages, namely data reduction, data presentation, and conclusion drawing.

\section{General Description of Mining Companies in Indonesia}

Indonesia is known as one of the countries in the world that is rich in natural resources, both natural resources that are above and under the ground level in the territory of the country. The utilization of natural resources can be carried out through mining activities, namely a series of activities which include extraction (excavation, dredging and desludging) and preparation for further processing of mining products, both in the form of solid objects, liquid objects, or gas. The results of this activity include oil and gas, coal, iron ore, tin ore, nickel, bauxite, copper, gold and silver.

After the enactment of Mining Law Number 11 of 1967 concerning the Basic Provisions of Mining and Foreign Investment Law Number 1 of 1967, mining activities in Indonesia have developed rapidly. The mining sector is divided into four sub-sectors, namely the coal, oil and gas, metals and other minerals, and rocks. The number of mining companies in each sector listed on the Indonesia Stock Exchange (IDX) in 2016 can be seen in Table 1.

\begin{tabular}{|l|l|l|}
\hline S.No & Sub sector & Number of companies \\
\hline 1 & Coal & 22 \\
\hline 2 & Oil and gas & 7 \\
\hline 3 & Other metals and minerals & 9 \\
\hline 4 & Rocks & 2 \\
\hline
\end{tabular}

Table 1: The number of mining companies listed on IDX.

The data in the table above shows that the coal mining sub-sector companies have the highest number, which is as many as 22 companies, followed by other metal and mineral sub-sectors as many as nine companies, then the oil and gas sub-sector as many as seven companies, and finally the sub-sector of rocks of two companies. The mining sector also includes the industrial sector which contributes greatly to the Gross Domestic Product (GDP) in addition to other industrial sectors as can be seen in the graph of Figure 1.

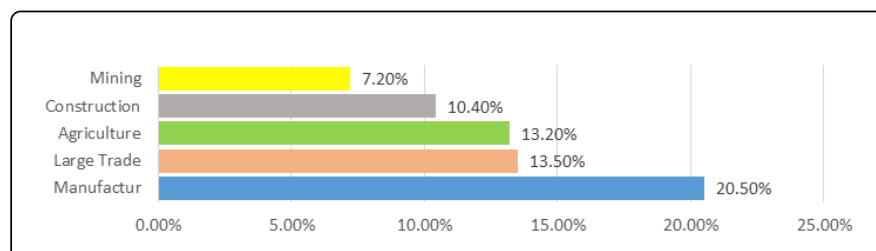

Figure 1: Mining sector contribution to 2016 GDP.

The above data shows that the mining sector contributed $7.2 \%$ to 2016 GDP, while the construction sector contributed $10.4 \%$, the agricultural sector contributed $13.2 \%$, the large trade sector contributed $13.5 \%$, and the manufacturer sector has the biggest contribution, which is $20.5 \%$. Although the contribution of the mining sector to GDP is still less than the other four sectors, the mining sector has the largest contribution to Non-Tax State Revenues (Figure 2). 
Page 5 of 8

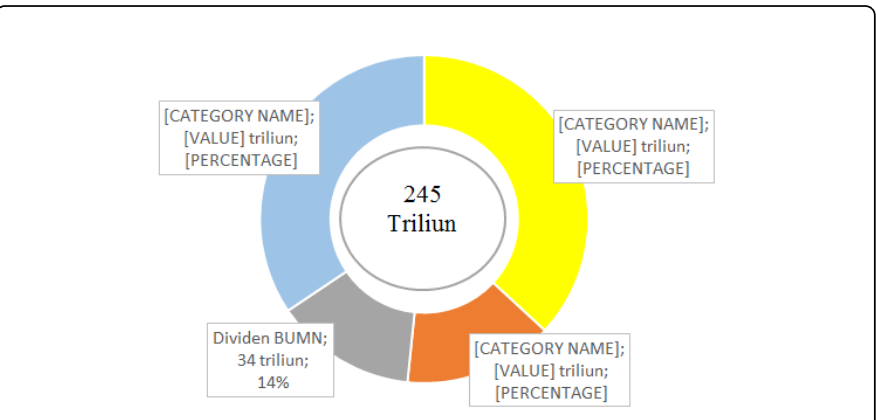

Figure 2: Mining sector contribution to PNPB 2016.

The data in the figure above shows that the mining sector was the largest contributor of PNPB with a contribution of 90 trillion or around $37 \%$, followed by other revenues of 84 trillion or $34 \%$, then the contribution of BLU Income was $15 \%$, and the last contribution from BUMN Dividends was 34 trillion or around $14 \%$. In addition, the mining sector is also the largest contributor to the General Land and Building Tax as can be seen in Figure 3.

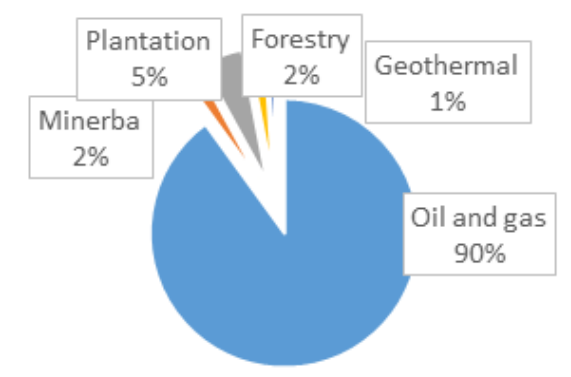

Figure 3: Contribution of mining sector to general land and building tax 2016 .

The data above shows that the mining sector is able to contribute 92\% (Oil and Gas and Mineral and Coal) to state revenues from the General Land and Building Tax, followed by the plantation sector by $5 \%$, then the Forestry sector by $2 \%$, and finally Geothermal by $1 \%$.

As stated in the Mining Law Number 11 of 1967 concerning the Main Provisions of Mining, activities in the mining sector include general investigations, exploration, exploitation, processing and refining, transportation, and sales. General investigations are general geological or geophysical investigations, landed, waters and from the air, everything with the intention of making general geological maps or for establishing signs of the presence of minerals in general. Exploration is all mining geological investigations to determine more thoroughly the nature of the extraction. Exploitation is a mining business with the intention of producing minerals and utilizing them. Processing and refining is workmanship to enhance the quality of minerals and to utilize and obtain the elements contained in the excavated material. Strengthening is any attempt to transfer excavated material and the results of processing and refining of excavated materials from exploration areas or processing/refining sites. Sales are all attempts to sell minerals and the results of processing/refining of minerals.
The above explanation shows that mining sector companies have an important role for the Indonesian economy. This is based on the suitability of the mining sector with the characteristics of Indonesia's natural wealth and on the contribution of the mining sector to GDP, PNPB, and the General Land and Building Tax of Indonesia.

\section{Result and Discussion}

\section{The effectiveness of Indonesian government regulations and legislations concerning prevention of tax avoidance practices in mining companies in Indonesia}

Tax avoidance is interpreted as an effort made by taxpayers to reduce or eliminate tax debts using methods that do not violate statutory provisions set by the state. Therefore, tax avoidance is a complicated matter because on one hand it does not violate regulations, while on the other hand it is something that the government does not want [23].

Tax avoidance is generally done by utilizing the weaknesses contained in the legislation, so that it can provide benefits to the taxpayer in the form of a minimum or even loss of the tax burden that must be paid. Although it is not classified as an act that violates the rules, tax avoidance actually makes the government unable to obtain taxes optimally. Therefore, the government strives as much as possible to suppress and prevent tax avoidance by establishing various policies and laws and regulations, as well as carrying out tighter supervision for the sector of the company which is indicated to carry out tax avoidance.

Companies engaged in the mining sector are included in the company sector which, according to the government, is indicated by a lot of fraud and tax avoidance. This is based on several government findings, among others in the form of data compiled by the Corruption Eradication Commission (KPK) which shows that $70 \%$ of holders of Mining Business Permits (IUP) apparently do not have a Tax Registration Number (NPWP). In addition, the data base of mining companies that are not integrated between those owned by the Ministry of Energy and Mineral Resources (ESDM) and the Directorate General of Taxes (DGT) is increasingly providing a loophole for the occurrence of tax fraud and avoidance. This is a serious problem because it can cause the country to suffer losses of up to 1,000 trillion.

The lack of integration of data between two government institutions with an interest in synergizing and supervising taxes, namely the Ministry of Energy and Mineral Resources and the DPJ, shows the weakness of government efforts to ensure mining companies carry out their taxes coupled with the self-assessment system implemented by the Indonesian government which makes the opportunity for mining companies to conduct tax avoidance.

If the tax calculation system is carried out independently and is not balanced by efforts to enforce strict tax regulations, then as good as any tax regulations and policies set by the government will not be effective in suppressing and preventing mining companies from conducting tax avoidance. This is in accordance with the orientation of positive accounting theory, that the existence of regulatory loopholes will make taxpayers try their best to use their ability, understanding, and accounting knowledge to regulate profits, one of which aims to do tax avoidance. 
In addition to requiring support in the form of strict enforcement of tax regulations, the effectiveness of government regulations also requires support in the form of beneficial ownership (BO) data from mining companies. $\mathrm{BO}$ is interpreted as the parties who are controlling the mining company, who are behind every important decision taken in the operations of the mining company, and are the party that gets the final benefit from the profits obtained by the mining company. Nevertheless, BOs are often not listed in official documents owned by mining companies. This makes it difficult for the government to find out the identity of the $\mathrm{BO}$, so that the government cannot optimally prevent tax avoidance from mining companies.

If referring to the explanation stated by Palan, tax avoidance actions carried out by a corporation can be seen in several characteristics, namely:

- There is a tax payment in a value smaller than the value that should be in accordance with the scope of legal interpretation;

- Payment of taxes is adjusted to the profits announced, not what is actually obtained; and

- There are efforts to delay payment of taxes.

These three characteristics can be found in mining companies that seek tax avoidance. Characteristics of late tax payments can be seen when mining companies are late in paying taxes for the 2011-2014 periods up to 35 trillion rupiah in 2016 . The characteristic of paying taxes is small and adjusted to the profits announced can be seen when mining companies pay taxes in a lower amount than they should, and do not provide sales data, so the DPJ cannot make comparisons to find out the amount of tax that mining companies should pay.

Some regulations and legislations stipulated by the government to prevent tax avoidance practices include:

- Article 18 paragraph 1 Income Tax Law (PPh. Act) and Minister of Finance Regulation (PMK) Number 169/PMK.03/2015 to prevent tax avoidance in the form of thin capitalization;

- Article 18 paragraph (2) PPh. Act to prevent tax avoidance in the form of controlled foreign corporation (CFC);

- Article 18 paragraph (3) Income Tax Law to prevent tax avoidance in the form of transfer pricing;

- PER-43/PJ/2010 to PER-32/PJ/2011 concerning the Application of the Principles of Business Fairness and Fairness in Transactions Between Taxpayers and Parties Having Special Relations; and

- PER-62/PJ/2009 to PER-25/PJ/2010 concerning Prevention of Misuse of Double Tax Avoidance Agreements to prevent tax avoidance in the form of shopping treaty.

Based on the various regulations, it can be seen some forms of tax avoidance that the government is trying to prevent, namely thin capitalization, controlled foreign corporation, transfer pricing, and treaty shopping.

Thin capitalization: Companies are considered conducting tax avoidance in the form of thin capitalization if they prioritize financing using interest-bearing debt rather than stock capital [24]. Government efforts to prevent tax avoidance in the form of thin capitalization are stipulated in Article 18 paragraph 1 of the Company Law, which states: "The Minister of Finance has the authority to issue a decision regarding the size of the ratio between debt and company capital for the purposes of tax calculation under this Law". With the existence of these provisions, the company can no longer unilaterally determine its financing based on debt rather than capital, but the comparison between sources of financing and capital must refer to the provisions of the finance minister

Controlled foreign corporation: The Company is said to carry out tax avoidance in the form of Controlled Foreign Corporation if the company transfers its income to another company that has a special relationship or is in control, which is located in a country with low taxes or does not even tax at all [25]. The government's efforts to prevent tax avoidance in the form of Controlled Foreign Corporation are set forth in Article 18 paragraph (2) of the Income Tax Law which states that:

- The amount of investment in the domestic taxpayer is at least $50 \%$ (fifty percent) of the total paid-up shares; or

- Together with other domestic taxpayers having a capital participation of at least $50 \%$ (fifty percent) of the total paid up shares".

Transfer pricing: The company is said to carry out tax avoidance in the form of transfer pricing if it sets the selling price that deviates from another party that has a special relationship, for example in a group of companies. Government efforts to prevent tax avoidance in the form of transfer pricing are set forth in Article 18 paragraph (3) of the Income Tax Law which states:

"The Director General of Taxes has the authority to determine the amount of income and reduction and determine debt as capital to calculate the amount of Taxable Income for Taxpayers who have special relationships with other Taxpayers in accordance with the fairness and prevalence of businesses that are not influenced by special relationships using the comparison method the price between an independent party, the resale price method, the cost-plus method, or other methods."

Other regulations which are also intended to prevent transfer pricing are stipulated in PER-43/PJ/2010 to PER-32/PJ/2011 concerning the application of principles of fairness and business fairness in transactions between taxpayers and parties with special relationships.

Treaty shopping: Companies are said to carry out tax avoidance in the form of treaty shopping if the company seeks to benefit from the existence of $\mathrm{P} 3 \mathrm{~B}$, when in fact the company does not have the right to do so. The government's effort to prevent tax avoidance in the form of treaty shopping is to set PER-62/PJ /2009 to PER-25/PJ/2010 concerning prevention of misuse of double tax avoidance agreements.

Various regulations set out to prevent the above tax avoidance if associated with tax avoidance problems that occur in mining companies are lack of relevance. In other words, the phenomenon of tax avoidance by mining companies is actually very simple, namely in the form of late tax payments, the least amount of tax paid, and the absence of good intentions to provide data needed by the government to compare the calculated tax value independently by mining companies with the tax value calculated by the government. In this case, mining companies are indeed classified as conducting tax avoidance in accordance with these characteristics, although not including the types of tax avoidance in the form of thin capitalization, transfer pricing, Controlled Foreign Corporation, and treaty shopping. Therefore, it can be said that regulations set by the government to prevent tax avoidance in general are appropriate, but have not been effective in dealing with tax avoidance by mining companies.

The practice of tax avoidance in mining companies can actually be overcome in a very basic way, namely by enforcing tax sanctions as 
stipulated in Law Number 28 of 2007 concerning General Provisions on Taxation (KUP), in the form of administrative sanctions (Articles $2 \mathrm{a}$ and $2 \mathrm{~b}$ ) and criminal sanctions (Article 39i). Article 2a states that taxpayers who pay their taxes after due date will be subject to a fine of $2 \%$ per month, calculated from the due date until the date of payment. Article $2 \mathrm{~b}$ states that taxpayers who have just paid taxes after the due date of submitting annual tax returns will be subject to a fine of $2 \%$ per month, calculated from the expiration of the SPT submission deadline to the date of payment, and part of the month calculated in full one month. Article 39 paragraph 1 describes criminal sanctions for people who do not deposit taxes that have been deducted or collected. The sanctions are imprisonment for a minimum of 6 months and a maximum of 6 years, as well as a fine of at least two times the tax payable and a maximum of four times the tax payable that is not paid or underpaid.

\section{Compatibility between regulations and legislation to prevent tax avoidance practices with taxation provisions in Indonesia}

Basically, government regulations aimed at preventing tax avoidance come from $18 \mathrm{UU}$ Ph. and from PER-43/PJ/2010 to PER-32/PJ/2011 concerning with the application of principles of fairness and business fairness in transactions between taxpayers and parties having special relations; and from PER-62/PJ/2009 to PER-25/PJ/2010 concerning Prevention of Misuse of Double Tax Avoidance Agreements. Article 18 The Company Law prioritizes the role of the Minister of Finance in terms of:

- Regulating the magnitude of the ratio between debt and corporate capital for tax calculation purposes to prevent thin capitalization; and

- Determine when obtaining dividends by domestic taxpayers on equity participation in overseas business entities other than business entities that sell their shares on the stock exchange to prevent controlled foreign corporation. In addition to setting the role of the minister of finance, Article 18 of the company law also encourages the director general of tax to prevent transfer pricing by giving authority to re-determine the amount of income and reduction and determine debt as capital to calculate the taxable income for taxpayers in accordance with the provisions stipulated in the law.

"The deadline and procedures for reporting tax deductions and collection by the treasurer of the government and certain bodies are regulated by or based on the Minister of Finance Regulation".

"Every government agency, institution, association and other party, is obliged to provide data and information relating to taxation to the Directorate General of Taxes whose provisions are regulated by Government Regulations taking into account the provisions referred to in Article 35 paragraph (2)."

"In the event that data and information as referred to in paragraph (1) are insufficient, the Director General of Taxes has the authority to collect data and information for the benefit of state revenues whose provisions are regulated by Government Regulations taking into account the provisions referred to in Article 35 paragraph (2)"

Tax avoidance is generally carried out by utilizing gaps in legislation that cannot be made in detail to overcome any phenomena or problems that arise in daily work practices (Suandy, 2008). Therefore, it is necessary to have an article of legislation that fills this gap with the flexibility of the provisions contained in it, namely in Article 3 paragraph $3 \mathrm{c}$ and Article 35A paragraph 1 and 2 of the KUP law, which are detailed in Article 18 of Law UUP paragraph 1.2 and 3. The synergy between regulations to prevent tax avoidance and taxation provisions in Indonesia has basically been able to become the foundation of enforcement of tax law in general and to prevent tax avoidance in particular.

\section{Conclusion}

Conclusions that can be drawn from this study include:

- Regulations and legislation established and implemented by the Indonesian government to prevent tax avoidance in general are appropriate. However, these regulations and legislation have not been effectively used to overcome tax avoidance by mining companies. This is because the practice of tax avoidance in mining companies is actually very simple, so it only requires the enforcement of strict tax sanctions.

- Regulations and legislation to prevent tax avoidance have met the provisions of taxation in Indonesia. This can be seen in the synergy between Article 18 of the Law on Income Tax paragraphs 1,2 and 3; General Tax Regulations, both PER-43/PJ/2010, PER-32/PJ/ 2011, PER-62/PJ/2009, and PER-25/PJ/2010 with Article 3 paragraph $3 \mathrm{c}$ and Article 35A paragraph 1 and 2 of Law Number 28 of 2007 concerning General Taxation Provisions.

\section{Theoretical implications}

This study contributes in the form of the application of accounting theory, especially positive accounting theory, to analyze the phenomenon of tax avoidance that occurs in mining companies. Basically, tax avoidance is carried out with the aim of minimizing the amount of tax that must be paid by taxpayers using methods that are not prohibited by law. The method used for tax avoidance is actually an application of positive accounting theory, namely to manipulate corporate financial data.

\section{Managerial implications}

Tax is an important income for the country. Therefore, both the government and mining companies need to be more serious in carrying out their roles and positions in order to encourage the development of the country. The government needs to enforce tax sanctions explicitly to mining companies that are proven to conduct tax avoidance, while mining companies need to demonstrate good business ethics, namely by complying with all government regulations related to taxation.

\section{Recommendations}

This research needs to be followed up through the conduct of further research which can re-examine the tax avoidance carried out by mining companies using quantitative methods to find out tax avoidance practices along with the factors that have influence on it.

\section{References}

1. Zain M (2008) Tax Management. Jakarta: Salemba Empat.

2. Dyreng SD, Hanlon M, Maydew EL (2008) Long-run corporate tax avoidance. Account Rev 83: 61-82.

3. Ronen P (2008) Tax havens and the commercialization of state sovereignty. Cornell University Press. International Organization. 
Citation: Luntungan D (2018) Critical Assessment of Prevention Policy Implementation of TAX Avoidance Practices Reviewed from the Accounting Perspective: A Study on Mining Companies in Indonesia. Int J Account Res 6: 183. doi:10.35248/2472-114X.18.6.183

Page 8 of 8

4. Jusup AH (2011) Fundamentals of Accounting. Publishing Section of YKPN College of Economics, Yogyakarta.

5. Tuankotta TM (1984) Accounting Theory. One Edition. Jakarta: LPFEUI.

6. Suwardjono (2005) Accounting Theory: Financial Reporting Engineering. Third edition. Yogyakarta: BPFE.

7. Ghozali I (2012) Accounting Theory, Issue 3, Semarang: The issuing body of Diponegoro University.

8. Setijaningsih HT (2012) Positive Accounting Theory and Economic Consequences. Accounting Journal 16: 427-438

9. Budiarto A, Murtanto SE (1999) Accounting Theory: from a Normative to Positive Approach. Journal of Business and Accounting.

10. Watts RL, Zimmerman JL (1986) Positive Accounting Theory, Prentice Hall International Inc, Englewood Cliffs, NJ, USA.

11. Watts RL, Zimmerman JL (1990) Positive Accounting Theory: A Ten Year Perspective. The Accounting Review 65: 131-156.

12. Januarti I (2004) Approaches and Critics of Positive Accounting Theory. Journal of Accounting \& Auditing 1: 83-94.

13. Jensen MC, Meckling WH (1976) The Theory of the Firm: Managerial Behaviour, Agency Cost, and Ownership Structure. Journal of Financial and Economics 3: 305-360.

14. Cornell B, Shapiro AC (1987) Corporate stakeholders and corporate finance. Financial Management, pp: 5-14.

15. Eisenhardt KM (1989) Agency theory: An assessment and review. Academy of Management Review 14: 57-74.
16. Kirchler E, Maciejovsky B, Schneider F (2002) Everyday representations of tax avoidance, tax evasion, and tax flight: Do legal differences matter? Journal of Economics Psycology 24: 535-553

17. Puspitasari C (2014) Effect of Leverage, Institutional Ownership, and Company Size on Tax Avoidance in Manufacturing Sector Companies Listed on the Indonesia Stock Exchange 2010-2012. Journal of Accounting 18: 14 .

18. Arnold BJ (2002) International Tax Primer. Kluwe Law International.

19. Lampreave P (2012) An Assessment of Anti-Tax Avoidance Doctrines in the United States and the European Union. Bulletin For International Taxation, pp: 153-169.

20. Gulo W (2010) Research methodology. Jakarta: Grasindo.

21. Creswell JW (2014) Research Design: Quantitative and qualitative approach. London: Sage Publishing.

22. Huberman M (2007) Qualitative Data Analysis, Bukit source for new methods. Jakarta: University of Indonesia Press.

23. Mulyani S, Wijayanti A, Masitoh E (2018) Effects of Corporate Governance on Tax Avoidance (Mining Companies Registered on the IDX). Journal of Accounting Research and Business in Airlangga 3: 322-340.

24. Gunadi (1994) Transfer Pricing, An Overview of Accounting, Management and Tax. Jakarta: PT. Bina Rena Pariwara.

25. Radiansah dan N (2015) Effect of Executive Character and Company Characteristics on Tax Avoidance (Tax avoidance). Accounting Scientific Journal 3: 782-816 